\title{
Transforming Student Engagement through Documentary and Critical Media Literacy
}

\author{
Jessie Daniels ${ }^{1}$
}

Young people entering college today have grown up in a multimedia environment, yet the classroom they most often encounter reflects nineteenth-century pedagogy. This paper explores the paradigm shift that is making documentaries more widely accessible for use in the classroom; describes a pedagogical strategy for connecting a critical media literacy 'reading' of documentaries with more traditional reading of written texts; investigates the effectiveness of this method to engage students through critical media literacy in ways that encourage transformation. Effectiveness was measured in a voluntary, self-reported questionnaire, emailed to students after the semester they took Introductory Sociology. Students in the sample favored the use of documentary films in the classroom, reported seeing connections between assigned readings and films, and said that because of the films they were more able to grasp core sociological concepts. [Article copies available for a fee from The Transformative Studies Institute. E-mail address: journal@transformativestudies.org

Website: http://www.transformativestudies.org (C2012 by The Transformative Studies Institute. All rights reserved.]

KEYWORDS: Sociology, Documentary, Pedagogy, Critical Media Literacy.

\footnotetext{
${ }^{1}$ Jessie Daniels, Ph.D., is Associate Professor of Urban Public Health (PhD, Sociology, University of Texas-Austin), and a Senior Fellow at the Center for Health, Media and Policy at Hunter College. She is the author of two books White Lies (Routledge, 1997) and Cyber Racism (Rowman \& Littlefield, 2009), both dealing with race, gender/sexuality and various forms of media. Acknowledgments: I would like to thank Paul Dean, Caroline Persell, Julie Netherland, Megha Ramaswamy, and Rebecca Tiger who read and commented on earlier drafts of this paper. Address correspondence to: Jessie Daniels, Hunter College, 695 Park Avenue, NY, NY 10065; e-mail: jessiedanielsnyc@gmail.com.
} 